\title{
BIRDS
}

\section{STATUS OF WADING BIRDS (ARDEIDS AND IBISES) AT THE NORTH END OF LAST MOUNTAIN LAKE IN 2006}

ROSS D. DICKSON, Canadian Wildlife Service, PO Box 280, Simpson SK SOG 4MO, ALAN R. SMITH and PHILIP S. TAYLOR, Canadian Wildlife Service, 115 Perimeter Road, Saskatoon SK S7N 0X4.

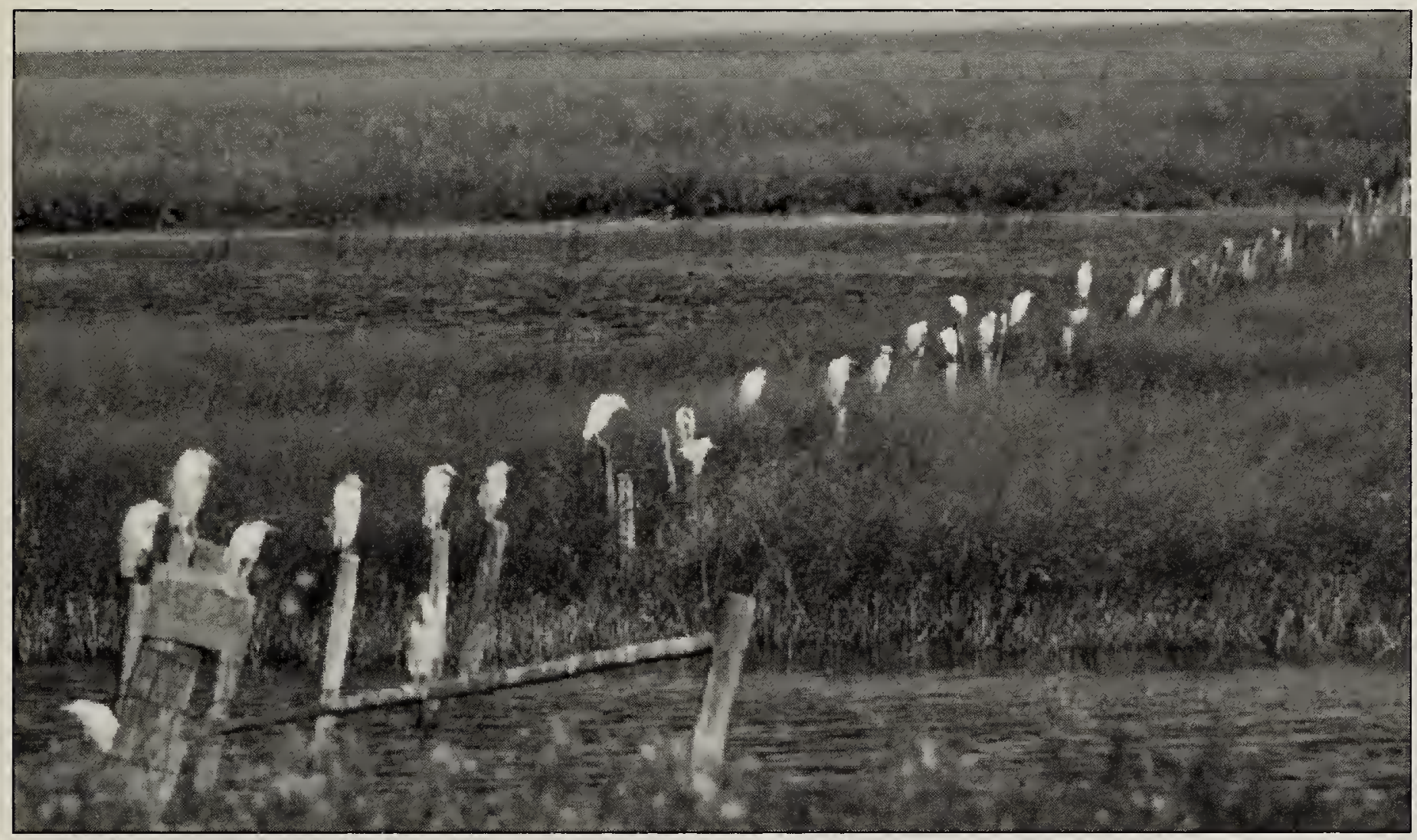

Figure 1. Cattle Egrets at the Borsheim project beside Highway 15 on 27 August 2006

V. Kjoss

The north end of Last Mountain Lake and surrounding wetlands may be one of the best areas in Saskatchewan to look for uncommon wading bird species, but the variety seen during the autumn of 2006 was extraordinary. Seven heron species: American Bittern, Great Blue Heron, Great Egret, Snowy Egret, Little Blue Heron, Cattle Egret and Black-crowned Night-Heron as well as the related White-faced Ibis were reported, some in unprecedented numbers. The only species previously reported for the area but not seen in 2006 is Tricolored Heron. This paper presents current information for wading bird species at the Last Mountain Lake National Wildlife Area (LMLNWA), supplemented by data from the nearby Stalwart NWA (Map 1.) Information on the Tricolored Heron is given in a separate note in this issue on page 111.

Species information was compiled mainly from Canadian Wildlife Service notebooks or reports, with additional data from graduate student reports and observations by visiting birders. Frequently cited observers are listed by their initials (ARS = Alan R. Smith, PST $=$ Philip S. Taylor, RDD = Ross D. Dickson, $\mathrm{WCH}=$ Wayne C. Harris). 


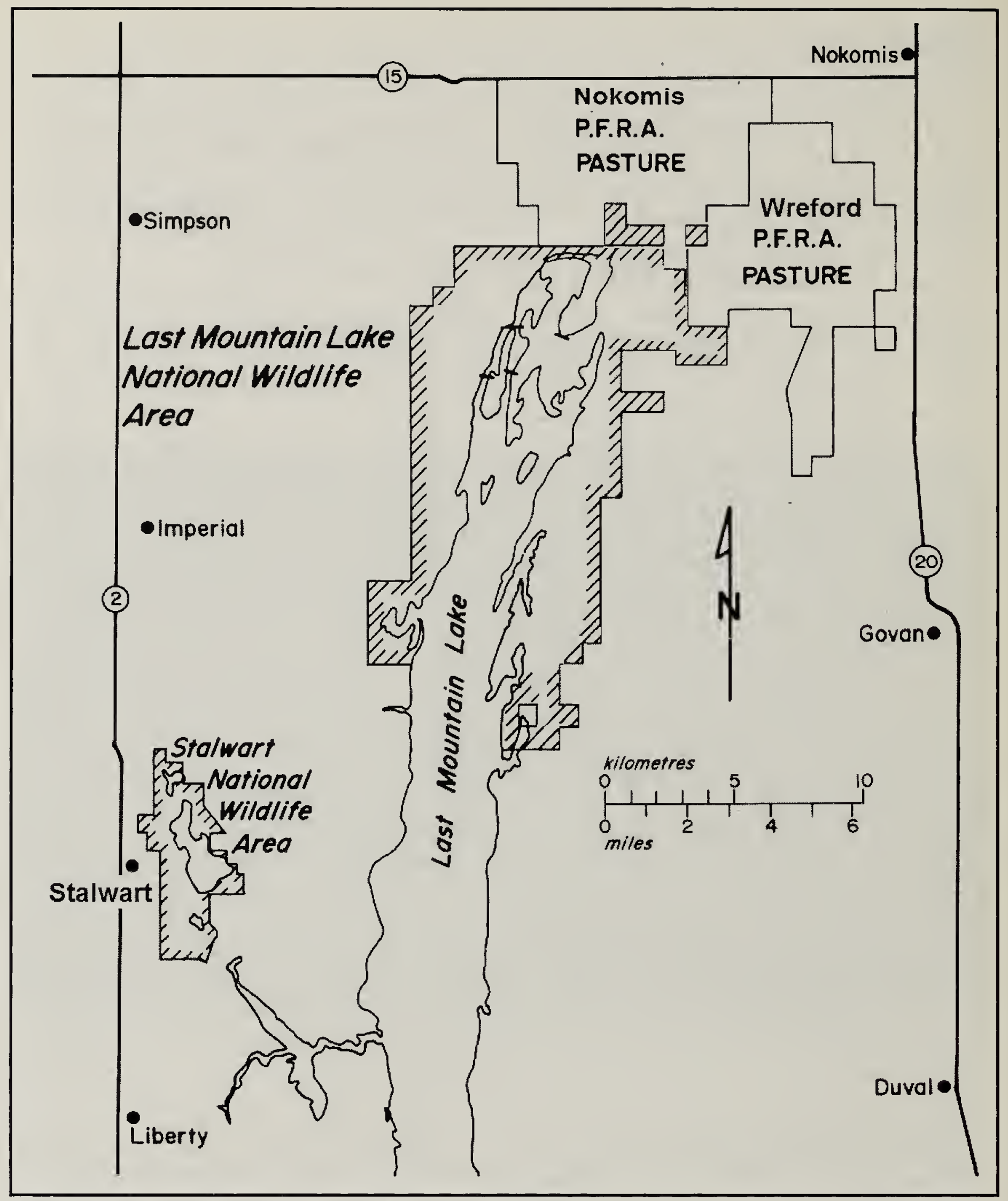

Map 1. The north end of Last Mountain Lake

Sightings of uncommon waders have been recorded in NWA annual reports since 1968. The status of all bird species was published in $1987 .{ }^{5}$ Some historical information about the presence of waders (or lack thereof) at the north end of the lake, often within the Migratory Bird Sanctuary (MBS, shown in Map 2), came from reports of expeditions sponsored by various museums, or from banding data.
For this paper, abundance and breeding status were taken from the 1995 bird checklist for both NWAs. ${ }^{9}$ An asterisk following the species name indicates historical breeding records. Common species are usually present from late April to late October, depending on ice cover. If autumn temperatures are above the long-term average, as in 1983, some individuals may linger into November. 


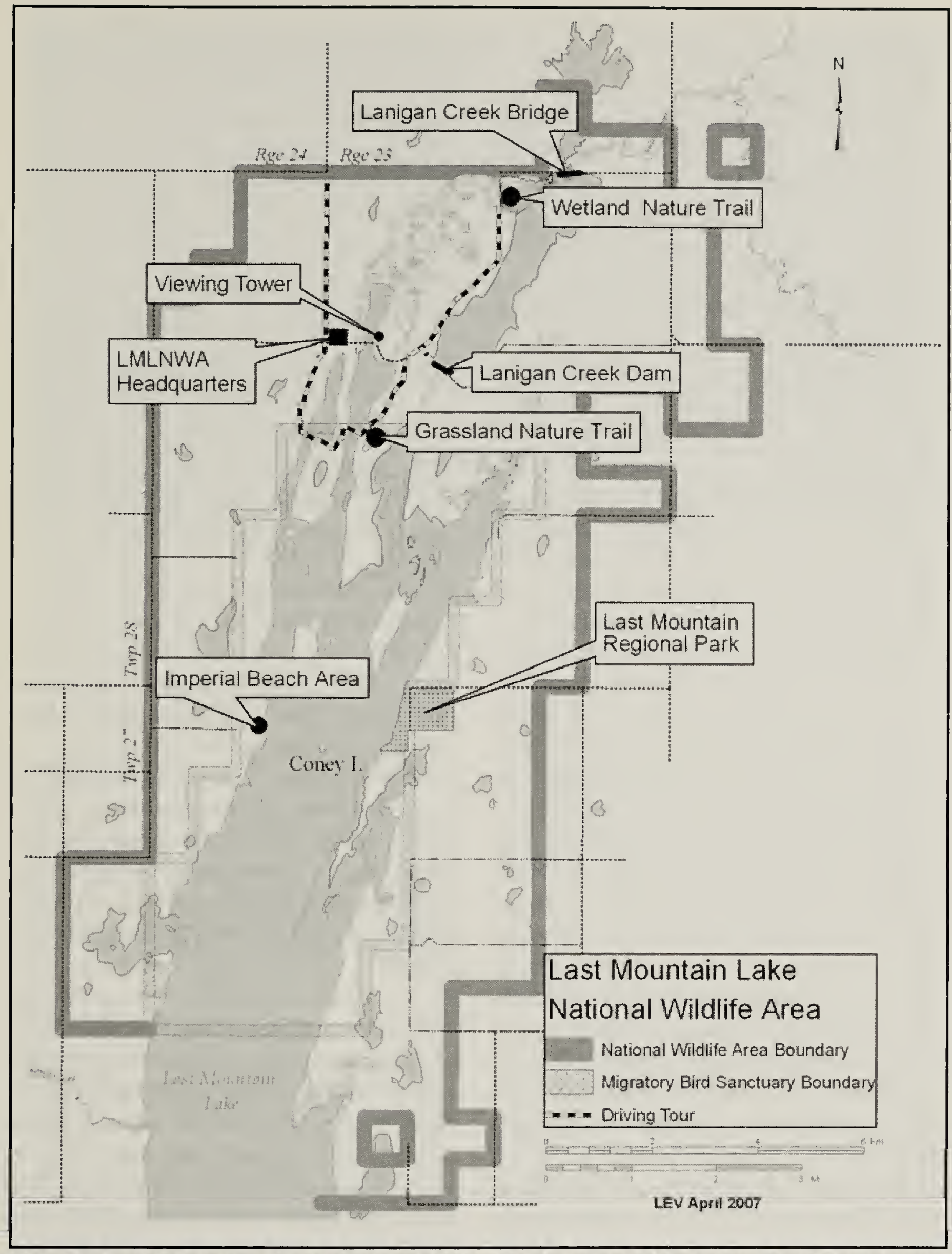

Map 2. Last Mountain Lake National Wildlife Area and Migratory Bird Sanctuary.

American Bittern Botaurus lentiginosus *

Common resident. Low-lying areas at the north end of LMLNWA were inundated by record high floodwaters in mid-April 2006. This created new habitat near the Driving Tour trails (Map 2) from which at least eight bitterns could be heard during early evening on 24 April (RDD). Following a prescribed burn of native grassland on a large peninsula nearby, an early May 2006 survey downstream of the Lanigan Creek Dam found one bittern per 500 $\mathrm{m}$ of shoreline (PST). In 2006, bitterns were noted from 24 April to 23 October. 
A late record was three birds on 12 November 1983 (WCH).

Wetland habitat loss is the major threat to American Bitterns across North America. ${ }^{11}$ Large marshes at Last Mountain Lake and Stalwart NWAs, however, are protected areas. Furthermore, the combination of changing water levels and patches of dense emergent vegetation produces ideal habitat for American Bittern. Its status at these NWAs has remained unchanged for the past 30 years.

\section{Great Blue Heron Ardea herodias}

Uncommon resident. Birders commented frequently during the autumn of 2006 on large numbers of Great Blue Herons. These herons were probably migrating birds and their high numbers may have been related to unusually high water levels in NWA marshy areas and dugouts. An informal survey of LMLNWA marsh shoreline in late September 2006 averaged one Great Blue Heron for every $0.8 \mathrm{~km}$ (RDD). This species is limited by food supply in most of its range, so adults are often territorial and well-separated in feeding areas. ${ }^{3}$ More than 30 years ago, the highest one-day count (43) occurred on 4 September 1973 for this heron which was then considered by observer Wayne Harris as a common migrant during early autumn. The Great Blue Heron is usually the first wader to arrive in spring. Reports in 2006 were from 10 April to 28 October. A late record was two birds 12 November 1983 $(\mathrm{WCH})$.

Although listed as a resident, this species has had no recent verified NWA records of successful breeding, perhaps due in part to scarcity of appropriate nesting habitat. This species often nests in colonies on treed islands or other isolated areas. Young herons were banded by Fred
Bard at "Imperial Beach area" (at a location believed to be within the current NWA boundaries) in 1936 and 1938 (Royal Saskatchewan Museum data). In late April 2005 and 2006, herons occupied up to six stick nests in trees on Coney Island west of Last Mountain Regional Park, but there were no summer visits to verify whether young were produced.

\section{Great Egret Ardea alba}

Occasional spring and summer visitor. (Figure 2) Frequent sightings of one or two birds near LMLNWA headquarters began in late May 2006 and continued sporadically into early autumn (many observers). Participants of a bird banding workshop watched seven Great Egrets fly to a bulrush (Scirpus spp.) roost southeast of the Grassland Nature Trail at sunset on 23 September. This is the highest number of Great Egrets recorded at one Saskatchewan location. Thereafter, numbers observed varied from three to six birds and the location of the nightly roost changed slightly within the Migratory Bird Sanctuary (ARS). The last sighting was of four on 8 October 2006 (RDD).

Previous Great Egret records at LMLNWA are of one or two birds, sometimes staying for a few weeks. The first record was on 11 May 1975 (WCH). Great Egrets were recorded in six separate years of the 1980s, and then not again until 2000, 2002 and 2005 (many observers). This long absence may indicate a low level of birding, although this species has a history of invading, then abruptly vacating, parts of its breeding range. ${ }^{17}$

This cosmopolitan species usually nests in colonies in trees or tall shrubs. ${ }^{17}$ Suitable nesting habitat appears to be limited within the NWAs. The duration of sightings in 2006 is 


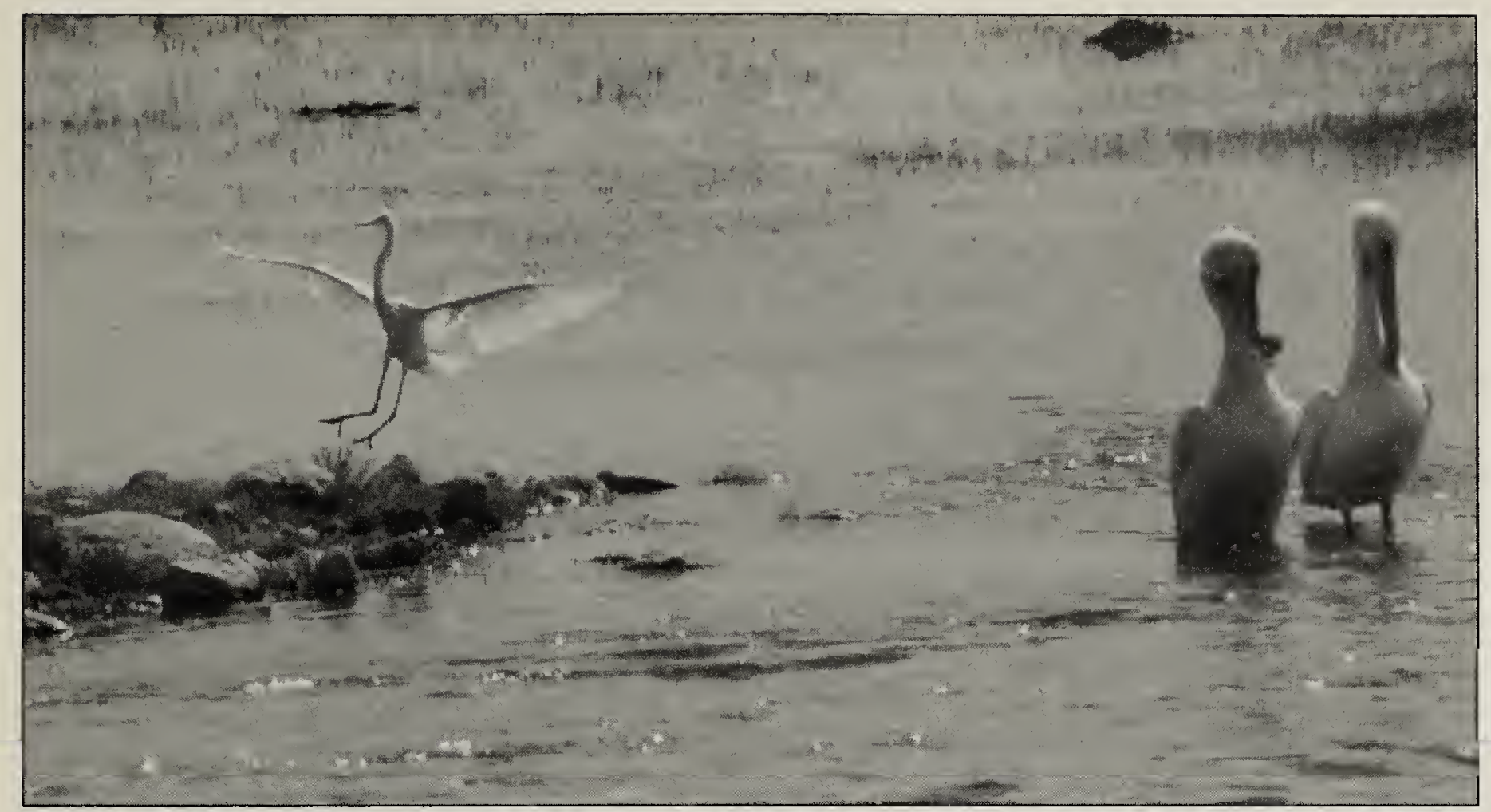

Figure 2. Great Egret and American White Pelicans, 14 May, 2006

V. Kjoss

intriguing as no nest was found. There are only two breeding records for Saskatchewan: east of Craven in the Qu'Appelle Valley in 1955 and Middle Quill Lakes in 1976. ${ }^{23}$

\section{Snowy Egret Egretta thula}

Occasional spring, summer or autumn visitor. A single bird, probably an adult, was seen feeding near a flock of Cattle Egrets on 28 August 2006 at the Ducks Unlimited Borsheim habitat enhancement project beside Highway 15 , about six kilometres north of LMLNWA (L. Strauss). A second 2006 sighting (possibly the same bird) was on 29 August in LMLNWA at Lanigan Creek Dam on the Driving Tour (ARS).

The first record of a Snowy Egret at LMLNWA was of a single bird on 17 July 1972 (J. Hatfield). Five records from the 1980s, two from the 1990s, and one in 2001 were each of one or two birds on single dates or for short durations (many observers). Four of the records were at Lanigan Creek Dam.

\section{Little Blue Heron Egretta caerulea}

Accidental (out of its usual range) summer. One adult ("small heron, all dark blue with pale patch at base of bill") was seen in flight near the Wetland Nature Trail on 9 September 2006 (A. Leighton, T. Leighton, B. Dewinter, D. Dewinter).

There were no further sightings until 3 October when one flew to a roost south of the Grassland Nature Trail (ARS). In good light conditions near sunset on 4 October one apparent adult circled repeatedly before landing at a bulrush roost shared with five Great Egrets and four Cattle Egrets (ARS, PST, RDD). The last known record was at the same roost in the MBS on 5 October (ARS). All sightings are assumed to be of the same bird. There are no photographs. The 2006 sightings represent the first Saskatchewan confirmed records since 1993.

This is only the second record for LMLNWA. An adult was identified at the dam on Lanigan Creek on 19-20 June 1976. ${ }^{13}$

\section{Cattle Egret Bubulcus ibis}

Accidental - spring and summer. Sightings in 2006 occurred over a five month period. An adult Cattle Egret was seen in a Highway 15 roadside ditch 


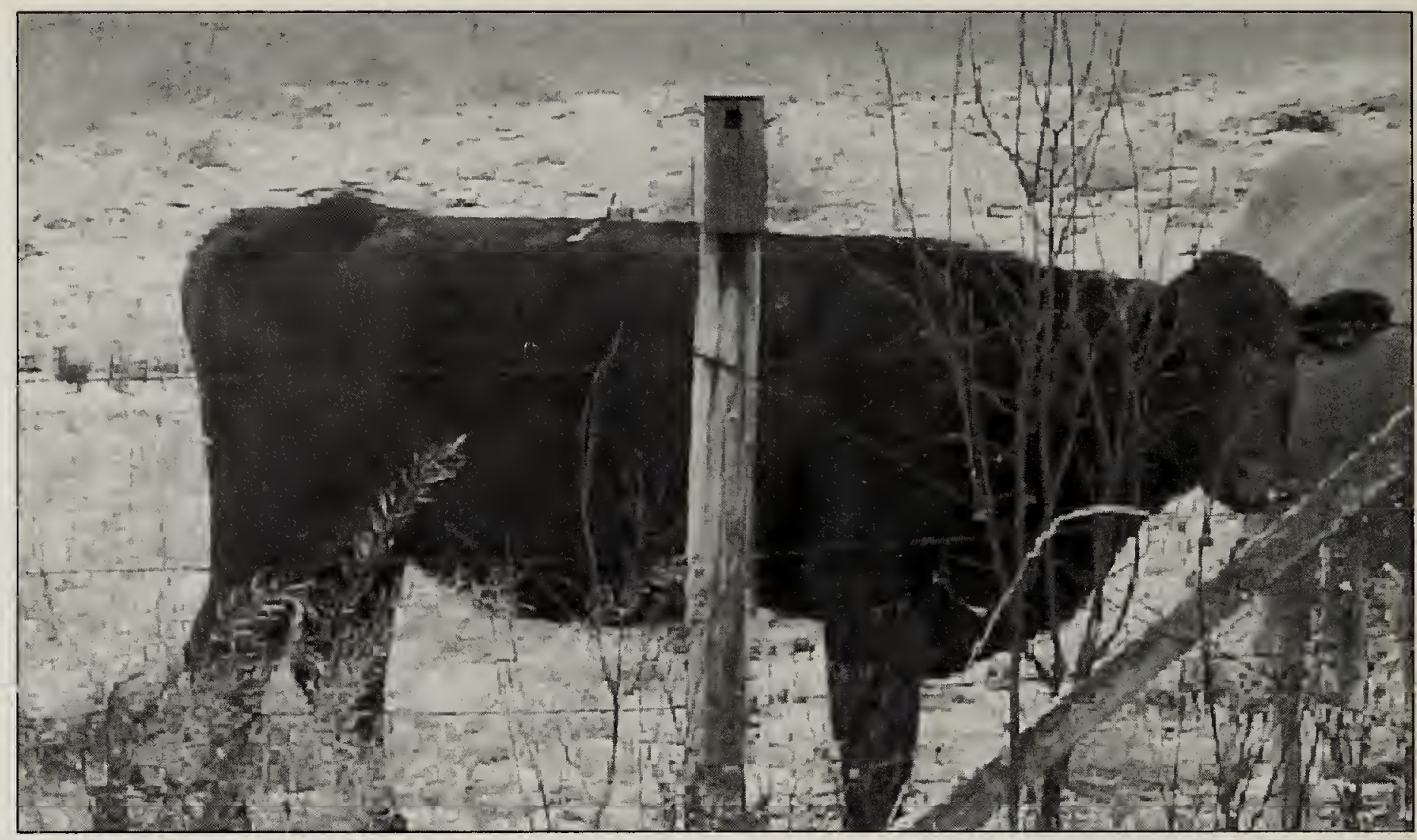

Figure 3. Cattle Egret on the back of a cow, 18 October 2006

R. Dickson

about six km north of LMLNWA in May 2006 (PST). A few adult birds were seen periodically during the summer flying within the MBS, but no search was made for nests. Beginning in early August 2006, a growing flock of adults was found associating with a cattle herd near the Highway 15 location. The highest number counted in this flock was 38 on 25 August, of which eight were believed to be recent fledglings characterized by a dark bill (RDD). (See September 2006 Blue Jay cover photo for a close look at a large dark-billed chick.) This is the largest group of Cattle Egrets reported at one Saskatchewan location. In the following days, other observers who did not get an exact count estimated this flock to have over 40 Cattle Egrets.

This flock rested occasionally during daylight hours at the Borsheim project. (Figure 1) The flock size fluctuated daily because some birds used alternate feeding locations. Each day, singles or small flocks flew along the marsh edges, sometimes joining one of the several cattle herds within the LMLNWA for periods of a few minutes to several hours. No attempt was made to determine the local diet of Cattle Egrets in late summer, although most foraging occurred beside grazing animals.

As overnight temperatures dropped, so too did the flock size but at least 13 Cattle Egrets shared a bulrush roost with seven Great Egrets on 23 September. That roost was last used on 8 October by 3 Cattle Egrets (RDD).

The remaining egrets then changed their allegiance to a herd of ten cows grazing near the LMLNWA headquarters. They walked among or rode on the cattle (Figure 3 ) and apparently stayed with them at night in a sheltered corral rather than flying to the bulrush roost. Overnight temperatures by then frequently dipped to about $-8^{\circ} \mathrm{C}$ and there were periodic snowfalls. It is doubtful the birds were finding any food at this time. By 18 October the egrets spent more time riding than walking with snow on the ground. Two lethargic egrets (one with a black bill and one with a yellow bill) were last seen alive on 19 October, standing on a lawn at the headquarters. 
A freshly dead egret was found on the morning of 20 October, about 200 $\mathrm{m}$ southeast of headquarters. This specimen was donated to the Royal Saskatchewan Museum. It had a completely yellow bill and blackish legs, which indicates that it was likely a nonbreeding adult. ${ }^{24}$ A necropsy is needed to verify its age and sex. The wing chord, tarsus length and culmen length (237 $\mathrm{mm}, 78 \mathrm{~mm}$ and $53 \mathrm{~mm}$, respectively) are within the normal size range of an adult measurement for the Texas population. ${ }^{24}$ It is possible that it died of starvation and/ or hypothermia. North American (Florida) adults range from $270-512 \mathrm{~g}$; this bird weighed only $258 \mathrm{~g}^{24}$

The Cattle Egret is well known for its juvenile dispersal after the breeding season. ${ }^{24}$ Occasionally, one of these egrets with a dark bill seen in late autumn may be misidentified as a Snowy Egret, but that species at any age has yellow feet. A recently-fledged young Cattle Egret may have a dark bill but its legs and tops of its toes will be a very dark (blackish) green; only the soles are yellowish. Any small white egret seen alive in October in Saskatchewan is likely to be a Cattle Egret, as the latest record for Snowy Egret is in early September (ARS).

The Cattle Egret in North America has an unusual nesting schedule, perhaps related to its probable African origin. The breeding season is prolonged (April-September) in the central flyway that includes Saskatchewan and Manitoba. ${ }^{24}$ Early summer surveys such as the Breeding Bird Survey that are satisfactory for most New World species may not detect any breeding evidence; chicks in nests at various stages of development were seen on 1 September 2005 in Manitoba. ${ }^{1}$ Only adults in breeding plumage were noted at Last Mountain Lake prior to midAugust.
If nesting occurred locally in 2006, the location of the colony is unknown. The only roost found was at a small bulrush stand within the MBS. In 2005, Cattle Egrets at Stalwart NWA roosted at night at their nest site, a common behaviour for this species.

In 2005, Cattle Egret nests with eggs were photographed (PST, K. Hecker) and fledglings were seen at a breeding colony shared with Black-crowned Night-Herons at Stalwart NWA. The peak number was 35 or 36 birds on 19 September with the last record of one bird of unknown age on 8 October (ARS, RDD). The bulrush stand in which the birds had nested in 2005 was flooded in 2006 and only two adult birds were seen at Stalwart NWA on 31 May (PST). No breeding activity was subsequently noted.

A late record of one apparently healthy dark-billed Cattle Egret on 18 October 2005, six kilometers north of LMLNWA was not regarded as noteworthy at the time. However, the first sighting of 2006 and the association with the cattle herd in late summer were at the same location. There is some indication that most Cattle Egrets disperse and establish residence while juveniles. ${ }^{24}$

Successful breeding has not been confirmed within LMLNWA boundaries although three or four adults were on an island northwest of Last Mountain Regional Park during the first week of June 1996 (PST, M. Tataryn). Numerous reports during the summer of up to four egrets in the Wreford PFRA pasture (Map 1) from late June to late July (M. Gee \& G. Thompson) preceded sightings of six egrets near LMLNWA headquarters in late July and of a flock in a field on the west side of the lake in mid-August 1996 (D. Nieman, C. Swoboda). The largest number (15) 
reported in that field, about two kilometres from the island visited in June, included two immature birds with black bills on 27 August 1996 (D. Nernberg, M. Tataryn). This supports the theory that Cattle Egrets likely nested on the island in 1996.

The dynamic range expansion of this species throughout the Americas since 1877 has been well documented. ${ }^{24}$ The first Cattle Egret reached Saskatchewan in 1974 and the species was first seen at the north end of Last Mountain Lake on 26 May 1984. ${ }^{12,14}$ This egret is now reported in Saskatchewan almost annually but there are only two published breeding records. ${ }^{20,21}$

\section{Black-crowned Night-Heron}

Nycticorax nycticorax *

Common resident. No estimate of their numbers is known for 2006, but sightings extended from early May until October 30. The latest reported date is on 12 November 1983 (WCH). An extremely early arrival date occurred on 29 March 2007. (L. Vanthuyne, RDD).

Night-herons may be found by patient birders along LMLNWA Driving Tour road where they appear to be fishing for ninespine stickleback (Pungitius pungitius) at the outlets of water control structures, or roosting in bulrush. They nest in colonies at both NWAs; 283 nests were counted 13 July 1984 at Stalwart NWA (D. Nernberg, M. Krystal).

The highest one-day count at Last Mountain Lake NWA is 72 adults on 27 May 1987 (WCH). The first NWA record was from 1930 (F. Bard). A rapid range expansion westward through southern Saskatchewan into Alberta began in the mid-1960s. Considered uncommon at LMLNWA as recently as $1977,{ }^{8}$ this species is often under-reported because it hides if disturbed. ${ }^{6}$

White-faced Ibis Plegadis chihi

Occasional - spring and summer. In 2006, several ibis were seen irregularly in LMLNWA within 70m of the Lanigan Creek bridge, beginning with a single bird on 1 September (R. Wapple). The largest flock (nine) was seen on 13 September (ARS, L. Parker), although most reports were of two or three birds (M. Yorke, M. Reid, others). After this area flooded following a rain event, some were found feeding beside the Wetland Nature Trail. The last record is of one ibis on 11 October (RDD). All local ibis records are assumed to be of White-faced Ibis as there are no confirmed records of Glossy Ibis for Saskatchewan. These species can be separated only when in adult plumage. $^{16}$

The first Saskatchewan record was one bird in 1976 east of Stalwart NWA. ${ }^{15}$ Three ibis seen on 15 May 1977 represent the first record for LMLNWA. ${ }^{4}$ LMLNWA sightings of one or two ibis are documented from April to October, sometimes for up to 4 weeks in duration; records exist for 1985, 1986 , 1987, 1990, 1994, 1996 (many observers). A single bird was seen in a field bordering LMLNWA on 23 April 2003 (L. Vanthuyne, J. Dunlop).

There are no verified nesting records at either NWA although the bulrush stands appear to be suitable habitat. Ibis were seen occasionally from 8 June to 24 July 1996 east of LMLNWA headquarters, and once appeared to be carrying nesting material (PST, $M$. Tataryn). A nest search attempted on 23 July 1996 located a pair of adults within a night-heron colony but no nest, eggs or young were found (PST, J. Dunlop).

It is likely that ibis have been under- 
reported at both NWAs. Shallow flooded wetlands or mudflats are favoured for feeding; these are often hidden from view by tall emergent vegetation. ${ }^{2} \mathrm{~A}$ pair of adults and one young at Old Wives Lake in July 2000 represent the only known breeding record for Saskatchewan. ${ }^{2}$

\section{Discussion}

Abundance and breeding status have changed for two wading bird species since the compilation of the 1995 NWA bird checklist. Great Blue Heron is now an uncommon breeding resident. Cattle Egret is an occasional breeding visitor. The status of the six other species discussed in this paper remains unchanged.

Will the number and variety of herons and ibis reported in 2006 occur again soon? Comparison of previous NWA checklists reveals a gradually increasing abundance for Great Blue Heron, Great Egret, Cattle Egret and White-faced Ibis. ${ }^{5,8,9}$ Southern ardeid species (Great Egret, Snowy Egret, Little Blue Heron, and Cattle Egret) and the ibis were unreported at the north end of Last Mountain Lake before the 1970s. Sightings also have increased following acquisition of land for LMLNWA, and construction of roads and impoundment berms that allowed birders better access to the marshes.

Managed water levels at Last Mountain Lake and Stalwart NWAs provide diverse marsh feeding habitat suitable for several wader species. Shallow flooded areas are especially productive for prey species such as crustaceans, amphibians and small fish, and serve as feeding areas for locally rare waders such as Little Blue Heron, Tricolored Heron, Snowy Egret and White-faced Ibis, as well as for bitterns and night-herons. ${ }^{10,11,18,19,22}$ The Great Blue Heron patrols the deepest water, often up to its belly. ${ }^{3}$ The Great Egret is considered a feeding habitat generalist. ${ }^{17}$ Extensive bulrush stands are potential nest sites for bitterns, night-herons and ibis.

Southern heron species that prefer to nest or roost in tree colonies appear to be limited by lack of suitable habitat within the NWAs. However, fire suppression has allowed aspen bluffs to develop in the nearby agricultural landscape. Some of these bluffs, as well as trees or shrubbery in shelterbelts within a short flying distance of the NWAs, may with time be large enough to attract more nesting attempts by Great Blue Herons. Great, Snowy and Cattle egrets, and the Little Blue Heron all colonize areas with tall shrubs or appropriate trees. The present combination of nearby cattle herds and existing night-heron colonies in dense emergent vegetation appears to be attractive to breeding Cattle Egrets.

All nesting ardeids and ibis are intolerant of disturbance, which sometimes comes from non-human sources. Competition for any suitable nesting trees at Last Mountain Lake by a rapidly increasing population of Double-crested Cormorants may occur eventually, although current cormorant colonies within LMLNWA are on treeless islands. At many inland sites, beaver ponds that flood woodlands kill the mature trees that would attract nesting Great Blue Herons.

Additional wader species are anticipated at the NWAs. Three uncommon ardeids recorded elsewhere in southern Saskatchewan are at the current northern limits of their respective ranges. Green Heron, which typically prefers dense thickets, has been reported at the Valeport Marsh.,23 Yellow-crowned Night-Heron prefers 
crayfish elsewhere in its range; this prey is abundant along the shores of Last Mountain Lake. ${ }^{25}$ The tiny Least Bittern, although unrecorded in Saskatchewan in more than 70 years, breeds south of Winnipeg and has been reported across Manitoba. ${ }^{16}$ Two additional ibis species (Glossy Ibis and White Ibis) have also been found in Manitoba wetlands. ${ }^{16}$ Permanent water at Last Mountain Lake and many years of data collection may permit it to be a baseline site to monitor changes in the abundance and range of wader species.

Increased knowledge of local roosting and breeding behaviour, in addition to observations by visiting birders, may result in much information being added in future years. Birders are encouraged to submit additional information on these or other bird species at any National Wildlife Area to the Area Manager at Last Mountain Lake NWA.

\section{Acknowledgements}

We are grateful to Gary Anweiler, Brenda Dale and Mark Tataryn for collecting and compiling bird records used in NWA checklists, and to John Hatfield, Clint Jorgenson, John Dunlop and Kerry Hecker for their wildlife observation summaries. We thank the many individuals who shared their bird sightings at the Last Mountain Lake and Stalwart National Wildlife Areas with the Canadian Wildlife Service. Helpful comments from an anonymous reviewer greatly improved the manuscript.

1. BAZIN, R. 2006. First documented breeding records of Cattle Egrets in Manitoba. Blue Jay 64(3):126-130.

2. BAZIN, R. and C. ARTUSO. 2006. First documented breeding record of White-faced Ibis in Manitoba. Blue Jay 64(2):64-68.
3. BUTLER, R. W. 1992. Great Blue Heron. In: The Birds of North America, No. 25 (A. Poole, P. Stettenheim, and F. Gill, eds.). Academy of Natural Sciences, Philadelphia and American Ornithologists' Union, Washington, DC

4. CALLIN, E.M. 1978. White-faced Ibis at Last Mountain Lake, Saskatchewan. Blue Jay 36:123.

5. DALE, B. 1987. The birds of Last Mountain Lake and Stalwart National Wildlife Areas, Saskatchewan. Blue Jay 45(4):246-260.

6. DAVIS, W. E., Jr. 1993. Black-crowned NightHeron (Nycticorax nycticorax). In: The Birds of North America, No. 74 (A. Poole and F. Gill, eds.). Academy of Natural Sciences, Philadelphia and American Ornithologists' Union, Washington, DC

7. DAVIS, W. E., Jr., and J. A. KUSHLAN. 1994. Green Heron (Butorides virescens). In: The Birds of North America, No. 129 (A. Poole and F. Gill, eds.). Academy of Natural Sciences, Philadelphia and American Ornithologists' Union, Washington, DC

8. ENVIRONMENT CANADA CANADIAN WILDLIFE SERVICE. 1977. Bird checklist: Last Mountain Lake Wildlife Management Unit.

9. ENVIRONMENT CANADA CANADIAN WILDLIFE SERVICE. 1995. Last Mountain Lake and Stalwart National Wildlife Areas bird checklist - fourth edition (1995).

10. FREDERICK, P. C. 1997. Tricolored Heron (Egretta tricolor). In: The Birds of North America, No. 306 (A. Poole and F. Gill, eds.). Academy of Natural Sciences, Philadelphia and American Ornithologists' Union, Washington, DC

11. GIBBS, J. P. , S. MELVIN, and F. A. REID. 1992. American Bittern. In: The Birds of North America, No. 18 (A. Poole, P. Stettenheim, and F. Gill, eds.). Academy of Natural Sciences, Philadelphia and American Ornithologists' Union, Washington, DC

12. GOLLOP, J. B. 1984. Prairie Provinces Region. American Birds 38:925-927.

13. HARRIS, W. C. and S. M. LAMONT. 1977. Little Blue Heron in Saskatchewan. Blue Jay 35:90.

14. HOUSTON, C. S and M. I. HOUSTON. 1974. Northern Great Plains (1 June-31 July 1974). American Birds 28:915-918.

15. LAHRMAN, F. W. 1976. White-faced Ibis in Saskatchewan. Blue Jay 34:328. 
16. MANITOBA AVIAN RESEARCH COMMITTEE. 2003. The Birds of Manitoba. Manitoba Naturalists Society, Winnipeg.

17. MCCRIMMON, D. A., Jr., J. C. OGDEN, and G. T. BANCROFT. 2001. Great Egret (Ardea alba). In: The Birds of North America, No. 570 (A. Poole and F. Gill, eds.). The Birds of North America, Inc., Philadelphia, PA.

18. PARSONS, K. C., and T. L. MASTER. 2000. Snowy Egret (Egretta thula). In: The Birds of North America, No. 489 (A. Poole and F. Gill, eds.). The Birds of North America, Inc., Philadelphia, PA.

19. RODGERS, J. A., Jr., and H. T. SMITH. 1995. Little Blue Heron (Egretta caerulea). In: The Birds of North America, No. 145 (A. Poole and F. Gill, eds.). Academy of Natural Sciences, Philadelphia: and American Ornithologists' Union, Washington, DC

20. RONEY, K. 1982. Cattle Egret nesting record for Saskatchewan. Blue Jay 40:163-164.
21. ROY, J.F. 1996. Cattle Egret. In Birds of the Elbow. Special publication- no. 21, Saskatchewan Natural History Society, Regina.

22. RYDER, R. A. and D. E. MANRY. 1994. White-faced Ibis (Plegadis chihi). In: The Birds of North America, No. 130 (A. Poole and F. Gill, eds.). Academy of Natural Sciences, Philadelphia and American Ornithologists' Union, Washington, DC

23. SMITH, A. R. 1996. Atlas of Saskatchewan birds. Special publication No. 22, Saskatchewan Natural History Society, Regina.

24. TELFAIR, R. C. II. 2006. Cattle Egret (Bubulcus ibis). In: The Birds of North America Online, No. 113 (A. Poole, ed.). Cornell Laboratory of Ornithology, Ithaca, New York.

25. WATTS, B. D. 1995. Yellow-crowned NightHeron (Nyctanassa violacea). In: The Birds of North America, No. 161 (A. Poole and F. Gill, eds.). Academy of Natural Sciences, Philadelphia and American Ornithologists' Union, Washington.

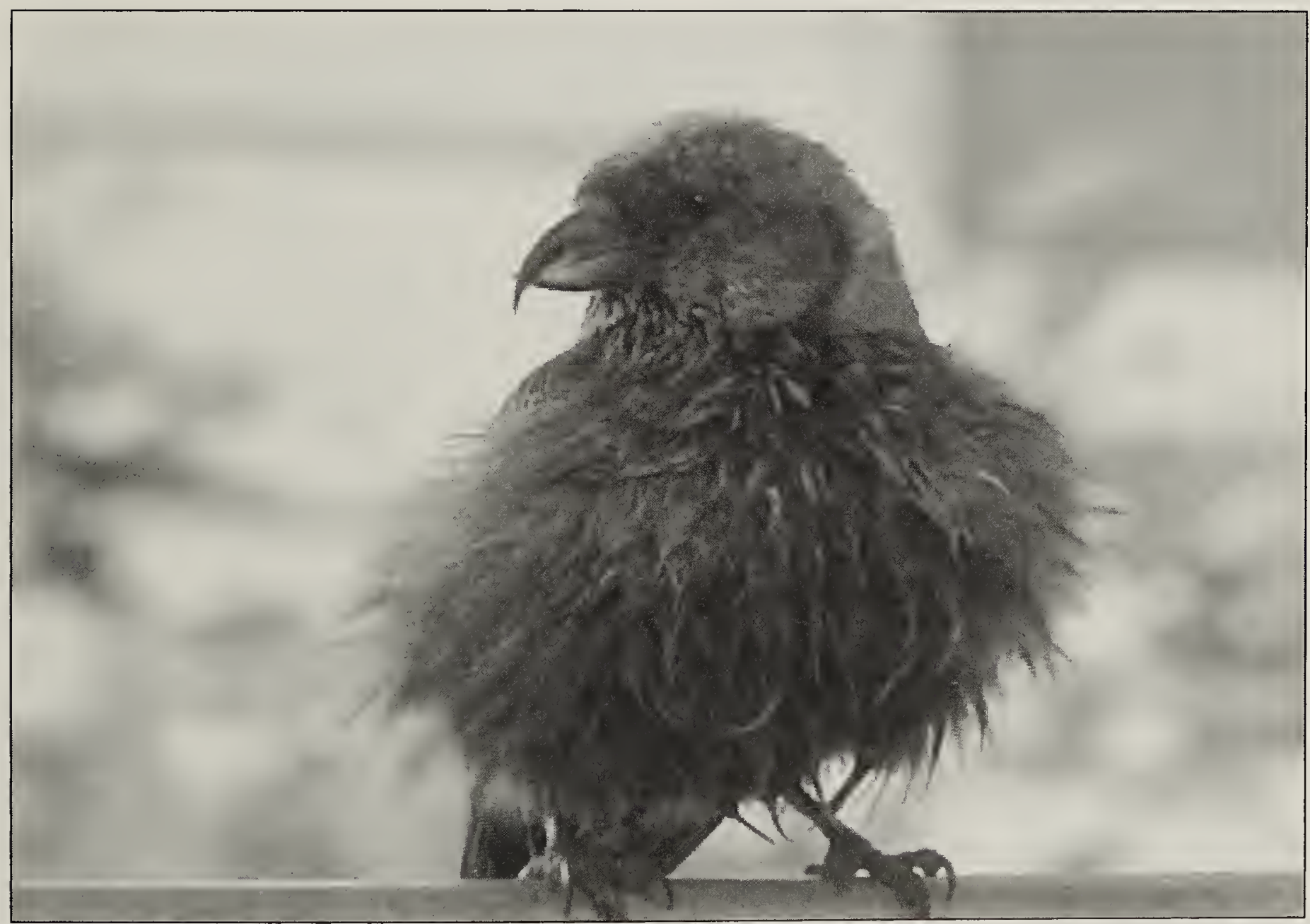

White-winged Crossbill after a bath in a water fountain in Swift Current.

Norris Currie 